http://spilplus.journals.ac.za/

$$
175
$$

\title{
DIE VERTAALBEROEF
}

EN TAALEEPIANNING

\author{
Anne-Har 1e Beuker
}

Departement Linguistiok on Literatuurwotengkap

Randse Afrikanse Universiteit

To plan language is to plan society.

- Cooper (1989: 182)

\section{INLEIDING}

Die fokus wat hierdie konferensie op die verhouding tussen taalwetenskap en taalprofessie plaas, is sekerlik van onmiddellike belang vir albei hierdie belangegroepe wat met vertaling te make het. Die belang hiervan setel myns insiens veral in twee kwessies:

(a) Die (oorbekende?) en onverkwiklike spanning tussen teorie en praktyk. Die volgende uitspraak van Arthur Langeveld is veelseggend:

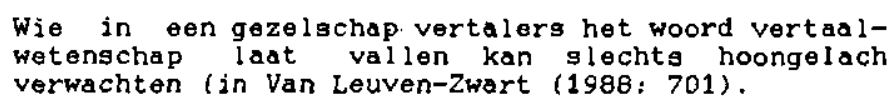

(b) Die bykans ongekende belangstelling in taalkwesgies en die aktiwiteit oor ' $n$ breë taalbeplanningsterrein wat dear tans in hierdie waterskeidingsperiode van ons Suid-Afrikaanse samelewing merkbaar is.

Die tweespalt tussen vertaalteorie en -praktyk is woreldwyd 
http://spilplus.journals.ac.za/

'n onhoudbare gituagie. Vertalerg is oënskynlik kwalik te oortuig dat die "suiwer", teoretieggerigte (ver)taalwetenskap met sy (vermeende?) ontoeganklike modelle en formules enige "lig" op die "werklike" vertalprobleme van die praktyk kan laat val. Ook (of gelfa?) toegepaste (ver)taalwetenskaplikes bring met moeite die "nut" van hulle ingigte onder skeptiege vertalers se aandag.

Vermoedelik sal die tweespalt op meer as een manier by hierdie konferengie an die orde gestel word. Ek gaan my dus liefg bemoei met die tweede kweggie hierbo en in die besonder dan die waarde van die vertaalberoep se betrokkenheid by taalbeplanning in ' $n$ veranderende Suid-Afrika.

Vertaling' speel immers ' $n$ sentrale rol in enige multitalige, multikulturele samelewing: tewens, as ' $n$. kommunikatiewe gebourtenis is vertaling onlosmakklik deel van die sosiale lewe en diskoerg in so 'n samelewing. Vertalers trangendeer as spesiale, professionele teksgebruikers die talige en kulturele grense binne 'n samelewing. Om ten volle diensbaar te kan wees, moet die vertaalberoep die diskoergbehoeftes en -patrone van die samelewing registreer en ver-

" "Vertaling" en ook "vertaler" word hier deurgaans in ' $n$ generiege gin gebruik en sluit daarom sowel "tolking" en "tolk" onderskeidelik in. 
http://spilplus.journals.ac.za/

177

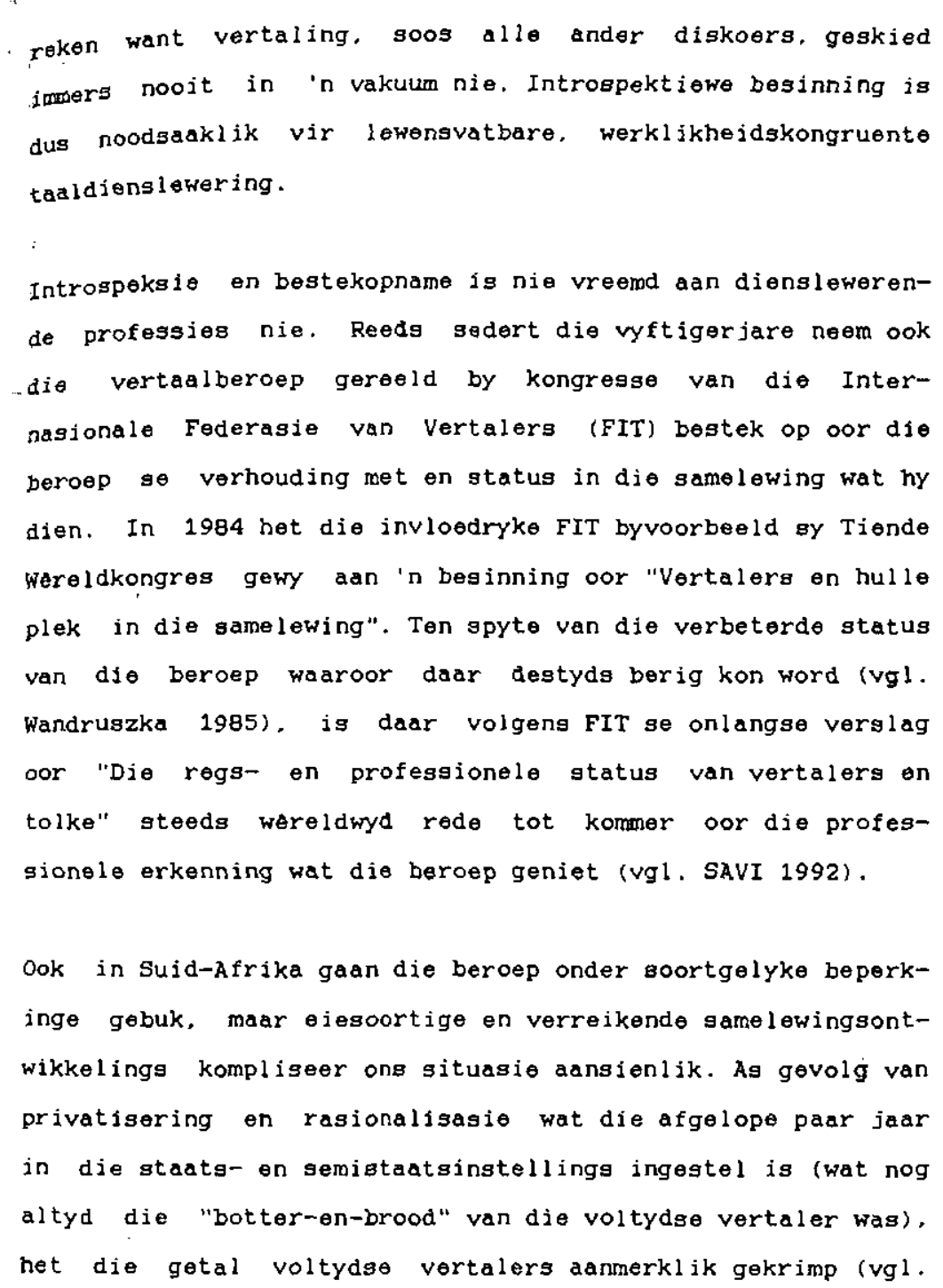


http://spilplus.journals.ac.za/

Kruger 1991). Die geīnstitusionaligeerde beroepsmoontlikhede met die gepaardgaande sekuriteit van 'n groot en vaste instellingstruktuur vir vertalers het gevolglik beduidond verminder. Maar die erkenning van die status van die beroep en die veranderde infrastrukturr is in suid-Afrika helaas net 'n deel van die problematiek wasmee die beroep nier te make net.

2 DIE KRISIS VAN DIE VERTAALBEROEP IN SUID-AFRIKA Vergeleke met die res van die wereld is die vertaaberoep in suid-Afrika tang in 'n erngtigo eksigtengiële krisis. Hierdie krisis is onder meer die resultat van die nuwe sogiale orde wat tot stand kom en wat nuutgedefinieerde kragte en behoefteg in ong gamelewing dikteer. Teen hierdie agtergrand wil ek argumenteer dat die vertalberoep hierdie krisis slegs sal "oorleef" as daar in ooreenstemning met die veranderende gemeenskap 'n herdefinjëring van die beroep plaasvind. Die ingrypend andersoortige amelewingsdinamiek van die nuwe Suid-Afrika vra 'n nietorlese mar ook oletydere hordefinfëring van die vertadberoep. Introspektiewe beglnning het dus dringend noodsaaklik geword godat die beroep ag't ware sy "Gestalt" in 'n nuwe samelewinggorde kan identifiseer en verstaan. Die vertaalberoep sal daarom opnuut no die mandaat van ong samelewing moet kyk indien ons ong begtaan in dio toekomg wil regverdig. 
http://spilplus.journals.ac.za/

179

n. Mistoriese herdefiniëring al 'n deurskouing moet behels van die aard en omvang van die tadongelyke, ondemokratiese gamelewingsbestel warin die vertalberoep in Suid-Afrika nie net sy beslag gekry het nie, maar inderdaad ook uitgebou en bestendig is. Die eietydse herdefiniëring sal ' $n$ besinning oor en aanvaarding. van die vertaalberoep se rol as. nas 'n fasiliteerder van kommunikasie, ook 'n agent van sogiale verandering behelo. En dit is hler war die vertaalperoep die insigte en werkswyses van die sosjaalgekonstrueerde terrein van taalbeplanning met vrug behoort te benut.

\section{3 'N SAMELEWINGSPERSPEKTIEF EN TAALBEPLANNING}

Die historiese en eietydse herdefiniëring van die vertaal- beroep sal midde-in ' $n$ proses van intense sosiale verandering moet plasuind. Taalbeplanning, as een van die meganismes warmee ' $n$ eamelewing sosiale verandering kan begtuur en waaraan die vertaalberoep uiteraard deel kan he, behoort die aangewese weg vir die beroep te wees. Trouens, Cooper (1989: 185) se:

Language planning, concerned with the management of change, is itself on instance of social change.

Ek wil dus argumenteer dat die insigte en meganismes van 'n teorie van taolbeplanning met sy gepaardgaande sosiale bemoeienis die vertalberoep se herkonstitueringsproses sal rig sodat die beroep nie slegs sal "oorleof" nie, maar " $n$ betekenisvolle bydrae sal lewer tot die vestiging en uitbouing van strukturele gelykheid en demokrasie in die toekoms- 
http://spilplus.journals.ac.za/

tige Suid-Afrika, want, soos Tollefson (1991: 202) inderdaad se :

(w)hile language planning reflects relationshipg of power, it can also be used to trangform them.

Meintjes (1991: 37) sien die opgaaf van die vertaalberoep in terme van aktiewe deelname in 'n bemagtigingsproses:

Tranglation in South Africa noeds to be directly implicated in the subvergion of power relations just as it has been implicated in the colonial appropriation of power through its mimicry of the dominant discourse(g) in the past.

In 'n gedemokratigeerde, veeltalige samelewing gal daar van die vertaalberoep verwag word om as fasiliteerder van kommunikasie al die inwoners in staat te stel om aan die politieke en ekonomiese diskoerg van die dag te kan deelneem. Die vertaalberoep het dus ' $n$ aktiewe rol te speel in die bemagtiging van taalminderhede in ' $n$ linguisties hoterogeno demokrasie. Die produk wat die beroep tot die begkikking van 'n gedemokratigeerde samelewing behoort te stel, is ' $n$ antilinguisistiese taaldienslewering wat taal- on kultuurgrense transendeer.

Mense se reg op gelykwaardige toegang tot digkoers met die owerheid en openbare ingtellings kan per definisie deur 'n doelmatige vertadberoep verseker word wat geingtitusionaliseerde diskoers in die moedertaal maksimaal moontlik mak. Tollefson (1991: 211) wys op die demokrasie se pertinente aandrang op die onderrig en gebruik van die individu se moedertaal as ' $n$ basiese mensereg: 
http://spilplus.journals.ac.za/

18.1

A commitment to democracy means that the use of the mother tongue at work and in school is a fundamental human right. ... this perspective ... measures social justice by the extent to which societies engure that individuals may use their mother tongues for education and employment.

4 'N INGTRUKENT VIR HERDEFINIERING: STRATEGIESE TAALBEPLANNING

Ondat die suid-Afrikaanse samelewing tons besonder vinnig verander, argumenteer ok dat die vertaalberoep ' $\mathrm{n} g \mathrm{~g}$. etrategiese benadering tot taabeplanning moet volg. Hierdie benadering verseker optimale kongruensie met dio ongewing en sy vereistes. Die vertaalboroop sal sodoende gy "produk". namlik antilinguisistiese taaldienslewering, bewugtelik in terme van ' $n$ bepaalde "mark" moet aanbied. Juis teen die agtergrond van die verskraalde, eksklusiewe vertalpraktyk van apartheid suid-Afrika, is dit van kardinale belang dat hierdie twe aspekte sentraal moet figureer in die beroep se herdefiniëringsproses.

Die strategiese talbeplanningsproses kan in terme van vyf stadia geëksplisiteer word (vgl. Figuur 1). Dit is 'n langdurige, berekende proses waarin die stadia interafhanklik en in onderlinge wisselwerking is.

S KONTEKSTUALISERING: 'N HISTORIES-STRUKTURELE PERSPEKTIEF

Ek gaan vervolgens aan die analige van die konteks waarbinne die vertalberoep in apartheid suid-Afrika gevestig is, an- 


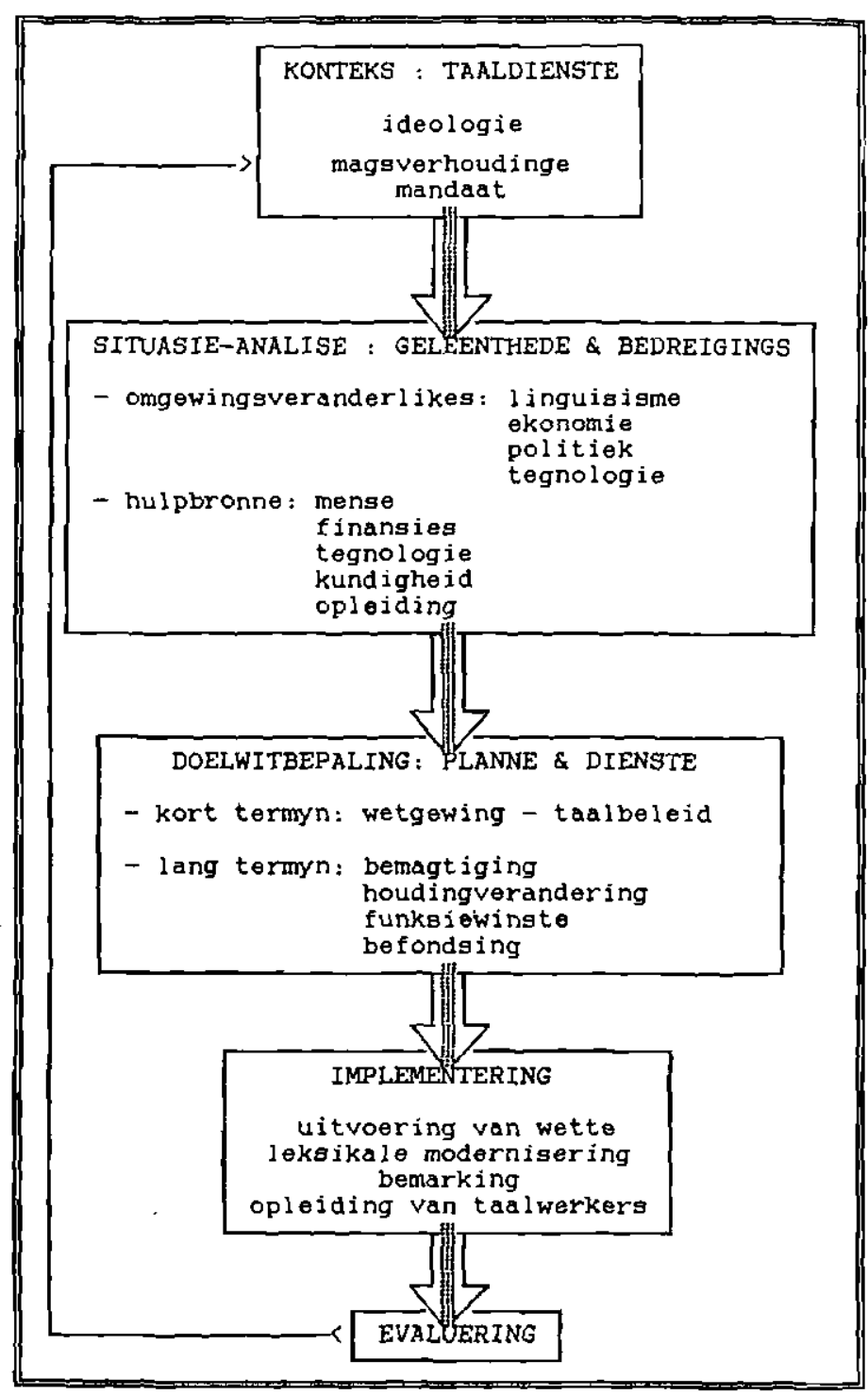

Figuur 1: Strategiese taslboplanning 
http://spilplus.journals.ac.za/

183

dag gee. Alhoewel dit binne taalbeplanningsperspektief as belangrik beskou word,

(1)anguage planning cannot be understood apart from its social context or apart from the history which produced that context (Cooper 1989: 183),

is dit ' $n$ aspek waroor die vertalberoop, met die uitsondering van Morris (1985); Siegrühn (1989) en (1990); Schutte (1990); Cluver (1990) en Meintjes (1991) tot op hodo relatief onkrities.was.

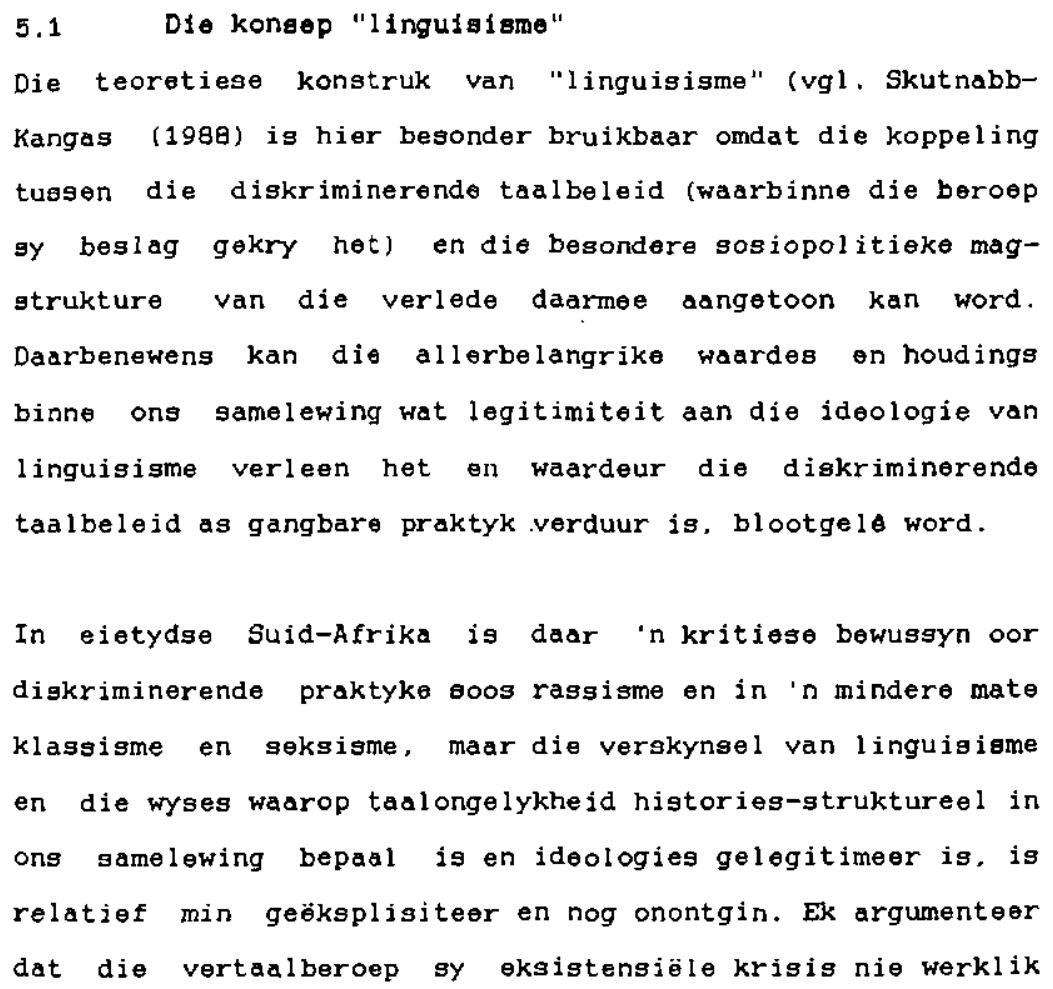


http://spilplus.journals.ac.za/

kan begryp alvoreng die linguigistiese gtrukture wat die profesgionele vertalpraktyk van die verlede gerig het, ge jdentifiseer is nie. Dus: die vertalberoep sal sy bydrae tot linguisisme in apartheid suid-Afrika moet herken en omlyn voordat 'n sinvolle eietydse herdefiniëring aangepak en 'n legitimiteitskrisig afgeweer kan word.

\subsection{DIe meganismes van lingulademe}

Linguigisme is natuurlik nie uniek aan Suid-Afrika nie. Dit kom wyd in sowel koloniale as postkoloniale Afrika voor. In die onafhanklikheidsdrif van die na-oorlogse Afrika het meeste van die nuutbevryde state die uitheemse, koloniale taal (of Engels, of Frang, of Portugees) as amptelike taal "gekieg" oënskynlik omdat die inheemse tale van die betrokke lande indertyd nie ag geskik geag is vir die uitvoering van regeringsake of vir die onderwyg nie. Mar op die keper begkou, is hierdie taalbeleid eintlik polities en ekonomies ingegee en operasionel gerig deur die hegemonie van die koloniale tale. Ook in Suid-Afrika is linguistiese minderheidsgroepe (ironies juis die inheemsetaalsprekers) naturlik deur hierdie linguigigme grootliks openbare diskoersmoontlikhede in die massamedia, regering, ens. ontge. 'n Kragtige meganisme van linguisisme is dat dit as gangbare praktyk, as "gegonde verstand", voorgehou word:

When minority languages do not appear in ... areas of public discourse, their exclugion comes to be seen as natural and inevitable (Tollefson 1991: 12). 
http://spilplus.journals.ac.za/

185

Phillipson (1988: 341) beskryf die destruktiewe werking van

linguisisme goos volg:

Lingulcist 1deology has affinities with the way racism is affirmed ... it essentially involveg the dominant group/language presenting an idealized image of itself. stigmatizing the dominated group/language, and rationalizing the relationship between the two. always to the advantage of the dominant group/language.

Postkoloniale regerings se beleid teenoor taalkwessies in Suid-Afrika reeds sedert die eerste besetting deur Nederland in 1652, ook die opeenvolgende Britse besettings tot die eietydse regerings het aantoonbaar die wesentlik veeltalige aard van ons samelewing telkens misken. Die Suid-Afrikaanse samelewing is van vroeg reeds as't ware "linguisties gedetermineer" deurdat die taalbehoeftes van slege 'n sekere deel van die Suid-Afrikaanse samelewing gedien is. Kortom: die doelwit met hierdie "ekskluaiewe" taalbeloid het veelal gesentreer rondom die konsolidering van mag on die fasilitering van diskoers tussen die owerheid on hoofsaaklik sy wit burgers.

5.3 Die vertaalberoep en linguiafome

Suid-Afrika se tweetaligo taalbeleid warin die res van die nagenoeg 9 hooftale grootliks geignoreer is, het verreikende implikagies vir die vertadsektor gehad. Dio linguisistiese aard van die vroeë taalbeleid word reeds in klousule 137 van die Zuid-Afrika Wet van 1909 ingegee:

De engelse alsmede de hollandse talen zijn officiële talen van de Unio zij worden op een voet van gelijkheid behandeld en bezitten en genieten gelijke vrijheid rechten en voorrechten. Alle akten, versiagen en 
http://spilplus.journals.ac.za/

186

verrichtingen van 't Parlement worden in beide talen gehouden en alle wetsontwerpen. wette en kenniggevingen van algemeen publiek gewicht of belang door de Regering van de Unie uitgegeven, zijn en geschieden in beiden talen.

Hierdie bewoording het bykans identies behoue gebly in die latere grondwette. Die verskafing van doelmatige taaldienste in die twee amptelike tale deur die owerheid is dus verplig deur en geskoei op hierdie linguigistiese, tweetaligheidalees en het daartoe gelei dat vertaling oor die afgelope driekwart eeu ' $n$ belangrike rol in die staat se kommikasiemasjinerie kon en moes speel.

As ' $n$ direkte uitvloeisel van die uitligting en gevolglike gelyke behandeling van Afrikaang en Engels het die owerheid in 1930 die destydse statsvertalburo gevestig. Die infrastruktuur om die tweetalige taalbeleid wit te voer is uitgebrei no ander owerheidskantore en statutere instellings waar alle amptelike publikasies, dokumente, wette en kenniggewinge slegs in die amptelike tale vertad word. Die statsen aemistaatsinstellings was nog altyd en is tans steeds, ten spyte van 'n afname in getalle (vgl. Kruger 1991: 15), die noofwerkgewerg vir voltydge vertalers in Suid-Afrika. 'n Erflating van linguisisme is aus dat die twee amptelike tale oorwegend die "botter-en-brood" van vertalers in die land is. Die onkritiese a anvaarding van die linguisistiese konteks waarbinne ons beroep hom bevind, blyk onder meer uit uitsprake soog die volgende (Picard in Siegrühn 1990: 24): 
http://spilplus.journals.ac.za/

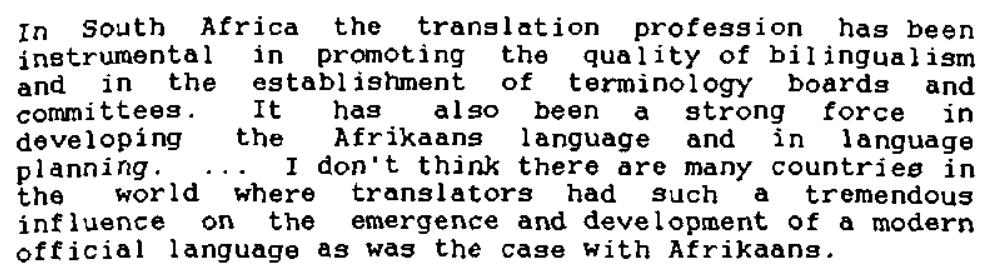
official language as was the case with Afrikang.

Die vertaalberoep kon hom in Suid-Afrika vestig op sterkte van 'n wetlik duidelik omlynde en beskermde vertaalsektor. Maar die beroep het ook 'n kardinale rol vervul as taabeplanningsagent in die implementering van die owerheid se linguisistiese taalbeleid (Cluver 1990: Schutte 1990; siegrühn 1990). So byvoorbeeld word met die organisatoriege ondersteuning van die staatgvertaalburo en die finansiële steun van die owerheid in 1950 die Vaktaalburo van die SA Akademie vir Wetenskap en Kuns gestig om "die vergameling. kollagionering. gtabilisering en aanvulling van Afrikaange wetenskaplike en tegniese terminologie" (aangehaal in Bosman 1959: 123) vanuit in sentrale punt te bevorder. Die koppeling tussen talbeleid en mag blyk duidelik uit die groter finangièle ondersteuning wat no 1948 vir die leksikale modernigering van Afrikaans begkikbaar gestel word (vgl. Morris 1985). Die koöptering van die vertaalboroep in die proses toon hoe kragtig die meganiame van linguisisme die belange van die owerheid en die groepe waraan die owerheid diengtig is, bevorder.

"n Tipiese gevolg van linguisigme is die marginalisering van die gedomineerde tale. Linguisisme in ons samelewing het 
http://spilplus.journals.ac.za/

gelei tot die hegemonie van ('n) taal/tale (hier Engels en ook Afrikaans) ten koste van die ander (inheemse) tale. Die relegering van die inheemse tale tot die domeine van veral die huig en kerk het vertaling in hierdie tale en ook hul lekgikale modernisering "onnodig" gemaak. Die linguisistiege beleid en meganismes is dus verantwoordelik vir gebrekkige ontwikkeling van die vaktale van die inheemse tale (Morris 1985, Swanepoel \& Morris 1988), asook vir die relatief onvol doende aandag aan navorsing in die verband (Fishman 1987).

As noodsaaklike skakel in die staatsapparaat se kommunikasie met die landsburgers het die vertaalberoep uiteraard geen geringe aandeel in die bestendiging van linguisisme gehad nie. Die owerheid kon die vertaalvaardighede in Suid-Afrika dus in ' $n$ sin monopoliseer sodat "die regte inligting" (Siegriuhn 1989: 18) vanuit die perspektief van die stat in vertaalde vorm beskikbaar kon kom. Daorbenewens was die vertaalberoep instrumenteel in die perpetuering van in ongelyke kommunikagiegtruktuur in die land met die uiteindelike taalagterstelling van die linguigtieso minderheidsgroepe. Teen hierdie agtergrond dus kan die stelling gemaak word dat die vertaalberoep in apartheid Suid-Afrika aantoonbaar ' $n$ besonder effektiewe meeloper van politieke en ekonomiese mag geword het. 
http://spilplus.journals.ac.za/

189

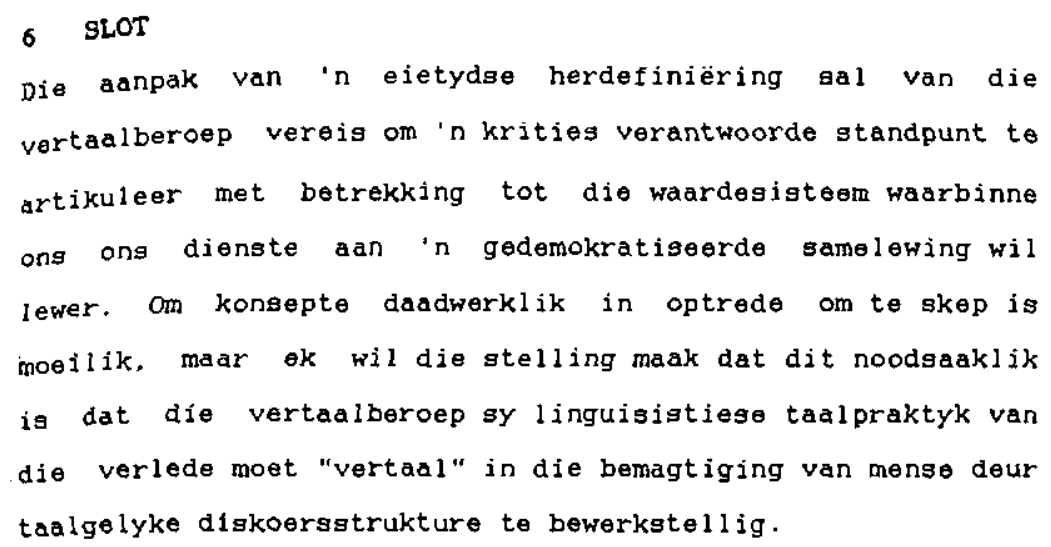

Die toekomstige, gedemokratiseerde Suid-Afrika gaan stellig

'n tweeledige opgaaf an die vertalberoep stel, naamlik om

(a) nas die fasilitering van kommikasie oor taalgrense heen kongruent aan die mandaat wat van die samelewing in die verband ontvang is, ook

(b) taalgebaseerde ongelykheid daadwerklik te help uitskakel 
http://spilplus.journals.ac.za/

190

sodat strukturele gelykheid in die nuwe demokrasie ge-

vestig en bestendig sal word.

En dit bring my uiteindelik weer by die vraag na die verband tugsen die taalwetengkap en taalprofessies. My tese is dat die werkswyge en die insigte wat taalbeplanning vir die vertalberoep bied. ' $n$ noodsaaklike lewenslyn kan wees in hierdie waterskeidingsperiode in sy bestaan. Want daar sal ongetwyfeld in die nabye toekoms van ons beroep gevra word om die rigting warin ong beweeg ondubbelginnig ten behoewe van die nutgedefinieerde gamelewing warin ons ons bovind, te artikuleer. Die relevansie van ons werksaamhede en ons sogialo bemoeienis gal geëvalueer word deur 'n samelewing wat nie weer sosiale risiko's in terme van ongelyke kommunikasiestrukture durf loop nie.

\section{BIBLIOGRAFIE}

Bogman, F.C.L. 1959. Geskiedkundige oorsig van die Akademie: Bevordering van dio Afrikaanse taal. In FEEBALBUM: DIE SA AKADEMIE VIR WETENSKAP EN KUNS. Pretoria: J.L. van Schaik, pp, 116-124.

CIuver, A.D. de V. 1990. Taalbeplanning en die taalprofessies. In SAVI BULLETIN, 5/90, pp. 4-5.

Cooper, Robert I. 1989. LANGUAGE PLANNING AND GOCIAL Change, Cambridge: Cambridge University Press.

Fishman. Joghua A. 1987. Research on national languages. In Armon, U., N. Dittmar \& K.J. Mattheier (redg.): SOCIOLINGUISTICS. Berlyn: Walter de Gruyter, pp. 638-646.

Kruger, Alet. 1991. Preliminary report: Translation and interpreting in South Africa. L1CCA REBEARCH 
PROGRAME. Universiteit van Pretoria.

Meintjes, Elizabeth. 1991. Translating for a new and progressive South Africa. In LANGUAGE PROJECTS REVIEW, $6(1 / 2)$, Augustus, pp. 35- 39 .

Morris, Rose. 1985. Lexical development and language planning in South Africa. In LANGUAGE PLANNING FOR SOUTH AFRICA, SA TYDSKRIF VIR TAALKUNDE. Occas1onal Papers no. 2, Julie, pp. 71-89.

Philipson, Robert. 1989. Linguicism: structures and ideologies in linguistic imperialism. In Skutnabb-Kangag, T. \& J. Cumming (reds.): MINORITY EDUCATION: FROM SHAME TO STRUGGLE. Clevedon: MUltilingual Matters, pp. 339-358.

SAVI. 1992. The profegsional status of transiators and interpreters. In SAVI BULLETIN. 1/92, PD. 4-6.

Schutte, J. 1990. The challenge of multilingualism - bridges and barrierg. SAVIREEKS no. 1 . Die SA Vertalersinstituut.

Siegrühn, A, 1989. Translation and the National Language Project. In LANGUAGE PROJECTS' REVIEN, 4(3). November. p. 18.

Siegrünn, A. 1990. Beginning an independent translation service. In LANGUAGE PROJECTS' REVIEW, 4(4). November, p. 24 .

Skutnabb-Kangas, Tove. 1988. Multilingualism and the education of minority children. In Skutnabb-Kangag, $T$. \& J. Cuniming (reds.): MINORITY EDUCATION: FROM SHAME TO STRUGGLE. Clevedon: Multilingual Matters, pp. 9-44.

Swanepoel, Piet \& Rose Morris. 1988. DIE REKENARISERING VAN TERMINOGRAFIESE PROSESSE. TERYNET-PROJEK IN DIE LEXINET-PROGRAM. Pretoria: R.G.N.

Tollefson, James W. 1991. PLANNING LANGUAGE, PLANNING INEQUALITY, LANGUAGE POLICY IN THE COMMUNITY, LONdEN \& New York: Longman.

Van Leuven-Zwart, Kitty. 1988. Vertalen en vertadwetenschap: Tweespalt of eenheid. In DE GIDS, 151(9), pp. 701-709.

Wandruszka. M. 1985. Tranglators and their position in gociety. In Buihler, H. (red.): Xth WORLD CONGRESS OF FIT. Wene: Wilhelm Braumuller, pp, 74-83. 